\title{
Turkey's E.U Membership: Perceptions, Possibilities, and Implications
}

\author{
Yusuf Ibrahim Gamawa ${ }^{1}$
}

\author{
${ }^{1}$ Bauchi State University, Gadau, Nigeria \\ Correspondence: Bauchi State University, Gadau, Nigeria.Email: yusufgamawa@ymail.com
}

Received: October 14, 2017

Accepted: October 28, 2017

Online Published: November 01, 2017

\begin{abstract}
The membership of Turkey into the European Union has remained as controversial as ever, even at this point when countries like U.K are leaving the EU, Turkey's membership in the Union is still being discussed in many circles. Though at this point it is clear Turkeys drive to join the EU appears to have dropped drastically and many believe that citizens of Turkey may no longer be interested in being part of the EU, the truth, however, remains that Turkey will always want to be in the EU, despite whatever disappointment. The pessimistic views are seen to be the result of previous disappointments and not that the Turks have lost hope or interest in the EU project. This paper aims to analyze the possibilities and implications of Turkey's membership of the EU and argues that membership of Turkey into the Union is still a possibility despite whatever implications it would have for Europe, especially if one considers the change in perception on both the side of Turkey and the EU regarding Turkey's membership bid.
\end{abstract}

Keywords: Capital Structure, Board Size, Board Duality.

\section{Introduction}

Turkey is generally seen to be a Muslim country mainly as a result of its history. The history of a nation and its destiny always move hand in hand, though dynamic changes could always occur. That the Ottoman Empire had its roots in Turkish soil makes it difficult for modern Turkey to separate itself from Ottoman culture, religion, and society in the eyes of the world. The Turks can never separate themselves from the Islamic empire that the Ottoman was, nor deny that an Islamic empire once flourished on Turkish soil. It is a past that is still alive, and which kept hunting the advances that the modern republic of Turkey has constantly been making to become a member of the European Union amongst many other reasons. To many people, it was incomprehensible that Turkey could aspire to become a member of the EU, owing mainly to its Ottoman past. Though sometimes this point is not clearly made but one can understand the rationale behind such thoughts. This thinking helped create a perception which is sometimes difficult to dismiss even among Turks themselves, and also helped influence the thinking amongst many people and nations regarding Turkey's EU membership bid. Despite favored in terms of its interaction and location to Europe, to many, it is unimaginable that Turkey should be counted as part of Europe or belonging to the EU. This more than anything else echoes each time the issue of Turkey's membership in the EU is mentioned, it remained unsettled in the minds of many. 
The Arab media from the early times remained critical of Turkey's effort to be an EU member, this is mainly due to the fact that many people including Arabs did not properly understand the concept of the European Union, and as such Turkey's 1987 application for membership had a bombshell effect on the Arab world. To many Arabs and Muslims, it was impossible for Turkey to be in the EU, seeing the EU membership as amounting to accepting Christianity, and or betrayal of the Islamic world. And there is no doubt that this perception exists with regards to Turkey's EU membership, and may have contributed in a way to many of the fears of Turkey being in the EU, despite the fact that religion isn't part of the conditions for membership. The membership application of Turkey seemed to have raised the issue of identity in the debate for accession, though not openly. It is mainly the complex history of Turkey that is making its candidature controversial though not impossible and has generated reactions from every part of the world, from leaders of nations in Africa, the Middle East to Europe, which tended to preserve the status quo, owing mainly to reactions from the Middle East. Reactions continued to come from scholars and even from ordinary people across the globe, with different opinions mainly negative regarding the issue. While many disagreed with Turkey's bid, yet others supported the bid of Turkey, and another group remained indifferent, but yet followed the development the membership bid with keen interest, contemplating its reality or not.

However, no matter the controversy the membership bid may have provoked, as well as the reactions it generated, the Turks have indicated their interest to be part of the EU long before now, and have taken concrete steps which demonstrated their commitment to actualizing their long-term ambition of becoming members of the EU. And though there is a significant change in perception over the years regarding the issue, and many people and nations came to understand what membership of the EU actually means to member nations. In 2005 when Turkey renewed its bid, the negative reactions could not be compared with that of 1987, and today there is a lot of improvement in the way many nations and people both within and outside Europe regarding Turkey's EU membership and many seemed to have come to terms with Turkey's ambition in this globalised world. And what is important at this critical stage now is to look at how far Turkey has progressed on the march towards its ambition over many years and why it has not yet become a member, despite several years of relationship with Europe, and at present despite many years of negotiation with the European Union. These are some of the questions we should be asking, and if we are able to find answers, and then probably more may come up, which may be futuristic in nature, such as; will Turkey become an EU member?And when? This is apart from many other questions which we may not want to discuss in this paper. Many have wondered why Turkey wants to join the EU, and on the other many wonders why it is still not a member. The two questions cannot be dismissed easily because just as many argue that the Turks haven't a place in Europe, others argue that the Turks have a prominent role and not just a place in the EU. While many see Turkey as having much to offer to the EU, others see nothing at all. The US president Barrack Obama was quoted by Yasser Abu Hilale of Jordan's Al-Gad newspaper in April 2009 as saying "Turkey must be part of the EU and that Turkey's geo-strategic importance, its culture, and its influential foreign policy will enrich Europe show his greatness". Open Society (2009) It is for these reasons that we as students must dig into the reasons and be able to come up with a concrete position on why on why Turkey is aspiring to become a member of the EU, and then look at the possibility of membership despite whatever problems we may have discovered in the process of our study, that may have been staining the relationship between Turkey and the EU and take a look at the future of this relationship.

\section{Membership Bid of the Republic of Turkey}

The republic of Turkey first made an application to join the European Commission as a member in 1959. Turkey as a nation, since it's founding in 1923, continued steadily to follow a policy of political, economic and social 
westernization under Mustapha Kemal with the aim of re-organizing their society to redefine Turkeys position in the world. But certainly, this is not to say that the Turks have not had relations with Europe before the founding of the republic. Relations between the Turks and Europe predate the republic, and relations with Europe flourished even during the times of the Ottomans. It is on record that the Ottoman empire did participate in the Paris peace conference of 1856 and the Berlin conference of 1878 in the nineteenth century. Alber Jens (2007) Not only that, during the first world war, the Ottomans were part of an alliance that included Germany and Austria, which were European countries, after the war between Turkey and Greece. Part of the explanation for Turkey's application to join the EC in 1959, was to check Greek influence in the region, it was a move that was necessitated by the dictates of the modern international system and politics. And in 1963, though membership was not granted to Turkey, an agreement was signed in Ankara, regulating Turkey's association with the European Commission. The Ankara agreement as it came to be known dealt mainly with trade and financial matters, and also prospects of full membership was offered during the agreement, though at an unspecified date. This marked a significant step in the history of Turkey's relationship with the European Commission, then the EU had not been formed. Turkey's intentions of joining Europe had been clear right from the beginning and remain the same till today. It would appear that the Turks have journeyed long to become part of the European community and have sacrificed their culture and identity by embracing that of Europe, all in an effort to be accepted. The Greek reason principally motivated the Turks to move into the European community, being surrounded by European nations. Apart from the Ankara agreement, in 1970 an additional protocol establishing a twenty-two-year transitional period leading to a customs union was signed between Turkey and the European Commission. However, at this time relations between Turkey and the EC received some setbacks as a result of Turkey's intervention in Cyprus in 1974, following a coup that was sponsored by the Greeks. It was much after the tensions had eased that between the duo, that in 1987, Turkey renewed its membership bid. Turgut Ozal, then Turkish Prime Minister, realized that Greek membership of the EC had put Turkey in a disadvantaged position and hoped to re-establish Turkey's position as a stable country and take advantage of membership to promote trade and Turkish products in the Mediterranean area. E.U Center (2008) The 1987 bid did not succeed for a number of reasons; the first being that the EC was at the pre-occupied with the creation of a European single market and as a result was not ready to accommodate new membership. The second reason was the issue of human rights and rights of minorities, with regards to the Kurdish people in the southern Anatolia. The EC further raised reservations regarding the ability of Turkey to implement the reforms required for membership and at the same time enlargement was suspended until 1993. It was the Copenhagen summit of 1993 that gave Turkey some hope of membership. It was at the summit that the decision to accept central and eastern European countries was taken since the collapse of communism in 1991, and a blueprint containing economic and political criteria for membership into the EC was also produced. In 1997, the European Council summit in Luxembourg did not consider the membership of Turkey, it was however at the Luxembourg summit that negotiations between Turkey and the EC froze. The council was said to have refused Turkey's membership because of the dispute on Cyprus and the Greeks. In Turkey, the Turks had a different opinion, and saw the decisions from mainly from religious and cultural angles. Such opinion was further influenced by the remarks of The European Christians Democratic Union to the effect that "The European Union is in the process of building a civilization in which Turkey has no place". E.U Center (2008) It was at the Helsinki summit in 1999 that the EU changed its position suddenly and reconfirmed Turkey's candidature to the EU, so long as it fulfilled the Copenhagen criteria of 1993 and resolved its long-standing conflict with Greece.

Between 1991 and 2002 a lot of positive events took place and were favorable to Turkey, among which are a 
change of government in Germany, which saw Turkey now has the support of Germany, and a new support from the US. Turkey's relations with Greece also improved considerably. Other factors were within Turkey, the coming of a new party to power as well as its commitment to continue with the reform program of the EU and ensuring stability in southern Turkey which had been a volatile area for many years. At this time Turkey offered to accept a UN plan for settlement in Cyprus. With these developments, an agreement was made in 2002 at the Copenhagen European council that accession negotiations could start in mid-2005 if Turkey could abide by the Copenhagen criteria. The criteria actually outlined three major areas

- A functional market economy with competitive pressures.

- Stability of institutions, guaranteeing democracy, the rule of law, good governance and human rights with respect for and protection of minorities.

- Capacity to take obligations of membership, including adherence to aims of a political, economic and monetary union.

The republic of Turkey had pursued a policy of reform long before the Copenhagen summit, reforms began since the founding of the republic, and subsequent government after Ataturk continued with these reforms in all areas. The significance of these reforms and policies embarked upon can be seen in the fact that when the Copenhagen criteria came out, the republic of Turkey already belonged to the camp of market economies. Many new coming members of the EU did not have a better market functional economy than Turkey, including Greece and Spain. Looking at the second criteria, one would say that since 1982, ran a parliamentary system of government, with elections and multi-party democracy with separation of powers. Two international nongovernmental organizations; Freedom House and Transparency International monitored the observance of good governance and human right, including corruption in Turkey. And the ratings of these organizations show that Turkey improved its rating year after year, steadily even though it was yet to meet the European standards of good governance. The progress Turkey was making was also recorded in the EU progress report on the accession process in 2006. The report indicated that there was a progress in the fight against corruption, though it faulted issues of human right and minorities, including freedom of the press, independence of the judiciary and rights of trade unions which it said remained impaired, and wanted Turkey to consider changes in these areas before full membership can be considered. It was however argued that there were countries which are members of EU whose rating in terms of political rights were far below that of Turkey, a country like Romania was rated as the EU worst by the Freedom House in 2007 and Transparency International in 1997 and 2007. Alber Jens (2007)

\section{Consequences of Turkey's Membership in the EU}

Many writers and political observers both within and outside of Europe that have been following Turkey's accession process into the EU, have on many occasions seen another side regarding the reasons why Turkey has failed to become a member of the EU. Many mention the fears other EU nation concerning Turkey and tended to look at the issues of reforms as mere excuses to stop the Turks. It is reported that many countries did not understand why Turkey wants to be in the EU, and it is generally agreed by many analysts with evidence that these fears do exist but the EU has never formally accepted and presented these reasons formally but has constantly used in full compliance with the Copenhagen criteria as a formal reason with other informal reasons behind. Some analysts see such criteria as deliberately crafted to block the membership bid of Turkey and for this many have wondered as to the actual reasons why Turkey is not considered in the EU, what are the fears if they really do exist? And the speculations are that 
- Size: The population of Turkey is about 70 million, and is projected to 100 million by 2020. If Turkey is admitted, it will become second to only Germany of $25 \mathrm{EU}$ states, it may become the largest EU member state in future.

- Economic development: The position of the economy of Turkey is seen as not very good, and below that of any of the ten EU states that joined in 2004, its GDP is just 2\% of the EU25 GDP PER CAPITA which is $28.5 \%$.

- Geographical location: Turkey is geographically located in Asia, and has long borders with states that are potentially unstable or hostile to the EU.

- Islamism: Turkey is overwhelmingly an Islamic country, Turkey's membership will increase the EU's Islamic population from 3\% currently to around 20\%. Nugent Neil (2005)

The nature of Turkey's threat to the EU is seen from different perspective by different analysts and political observers. They argue that Turkey's accession would have a great impact on the EU and its institutions, it would have great effect also in other EU member countries, and many countries will lose presence in the EU. In fact even the decision making process in the EU is seen to change due to the influence of Turkey if it becomes a member state. It is also thought that the size of Turkey and its economic under development will result in Turkey becoming the major beneficiary of EU's funding program. But also the nature of concerns vary among the individual EU states, though it generally agreed that there is stiff opposition to Turkey's membership among the relevant actors within the EU. Germany has been traditionally opposed to Turkey's bid until recently, while France till now remains opposed to Turkey joining the, Sarkozy openly showed his strong opposition to Turkey's membership. The UK and the U.S. have shown strong support for Turkey. Whereas Greece was opposed to Turkey's membership, but recently took a turn to support Turkey, following pressure from UK and US. Austria is also opposed to Turkey's membership, and the current Chancellor was quoted as saying "Turkey in the EU would mean the end of EU". Nugent Neil (2005)

But even as these fears are raised by EU member countries, of the threat of Turkey, yet many analysts see the positive aspect of the implication of European integration of Turkey. It is argued that, the population of Turkey, which is about 70 million, is a large market for the EU, and as a result of the customs union, all barriers to trade have long been eliminated. Yet another advantage is seen in terms of labor market. The Turkish population is seen to have much younger workforce population than the EU 25. The Commissions projections shows that the EU 25's total population will increase by 2\% (449-458 million) between 2005 to 2025, its working population falling by $21 \%$, from 2005 to 2030 , the number over 65 years will rise by $52.3 \%$, while $14-64$ age group will decrease by $6.8 \%$ resulting in the ratio of dependent and old people. In Turkey the working age group will increase from $49 \%$ in 2005 to 66\% in 2030 (European Commission). The Turkish workforce can complement human resource in many of the EU 25 nations in different fields. Even the issue of Islamism is viewed from another perspective. The UK's support for Turkey stems from the thinking that admitting an Islamic populated country like Turkey to the EU will serve to demonstrate that Islam, democracy and western capitalism can mix, to encourage moderate Islamism, and may also help EU member countries have softer influence and understanding for other Islamic populated countries.

\section{The Future of Turkey's EU Membership}

The article published by the European Commission in its progress report on Turkey, on 10 October, 2012 by Stefan Fule, quoted Fule from the beginning saying "Orhan Pamuk said that Turkey's EU project has fallen apart. These words coming from a Nobel Prize winner and a writer of books I admire made a big impression on me. As European Commissioner responsible for enlargement policy, I deal on daily basis with various aspects of 
EU-Turkey relations and I can certainly say that our joint project has not been abandoned; on the contrary, important initiatives have injected new energy and new hope. But I do think Pamuk's words reflect the mood often felt on both sides and they come at the right moment. I see them as a wakeup call, at a time when the EU and Turkey are at crossroads and need to take decisive steps forward on their common path". Stefan went on to highlight many of the challenges facing the EU and Turkey, but at the same time insisting that a lot of progress has been made in many areas and what remains to be finished should be finished saying "When I ask my Turkish partners where they see Turkey in five, ten, twenty years from now, they all say anchored in Europe. When I put the same questions to my intercalators and politicians in the EU, the answer is the same; they see Turkey's future as a modern European state. Mr. Stefan concluded his article with the following words "When I first came to Turkey as EU Commissioner nearly three years ago; I believed Turkey can become a member of the European Union. We have a joint commitment towards this goal". Fule Stefan (2012)

Based on the above, one can say with some confidence, that Turkey becoming a member of the E.U is a possibility that cannot be ruled out, despite whatever problems that may exist. And many agree unlike before, that the resistance to Turkey's membership has reduced drastically over the years. In the pre 2000 period, many reasons including Islamism were given, and there were stiff oppositions from all sides. As mentioned in the introduction a very strong perception was formed about Turkey with regards to the EU, which many tried to see from a religious angle? Even among Muslim nations, Turkey's membership of the EU could not be entirely understood.

An article by the Tribune Media Services titled "Does Europe want Turkey? Posted on the internet in 2005, was quoted as saying "The Paris October 11, 2005, European Union's decision to open talks with Turkey is another act of polite duplicity, another social lie, so to speak, in the EU's dealings with Turkey". And in another part, it said "That is why it was no service to Europe or to Turkey for EU leaders to have encouraged a Turkish bid for membership in a Europe that does not want Turkey. Why not? Turkey is not Europe. It is intimately involved in Europe's history, but the defining qualities of Europe derive from Attic Greece and Christianity to both which Turkey is foreign. This clearly expresses such negative perceptions regarding Turkey and the EU over the years. Tribune Media (2005)

Yet, another graduate student of Mathematics, from Idaho state University in U.S., back in 2005 posted an article on the internet titled "The real reasons why Turkey is not allowed in the EU". In the article, this graduate student appeared to be attacking one Mr. Guaugliardo, who had earlier written an article on the $1^{\text {st }}$ of October, 2004 giving reasons for Turkey's nonadmittance into the EU to include religion. But the graduate student in his article on www.math.isu.edu dismissed the issue of religion and insisted that Mr. Guaugliardo's article was misleading, and maintained that the Cyprus dispute and human right issues remain the only stumbling blocks to Turkey's membership in the EU. Aristidou Michael (2004)

And today everything looks different. Even in the Arab world, today Turkeys bid is seen in a positive light, and likewise in Europe, considering the recent support from Germany, UK and the U.S. as well as Greece, the ancient old rivals, are now all in support of Turkey's membership. The negotiating framework has made it clear that candidates whose accession could have substantial financial consequences (i.e. Turkey) the talks could only be concluded after 2014, which is the date for the establishment of EU's new financial framework. This also gives more hope to the EU-Turkey joint membership project. There are about four scenarios analyzed regarding the future of Turkey and the EU. The first scenario sees popular disenchantment with enlargement ceding, and demographic pressure could convince EU member states to admit Turkey.EU Center (2008) The second is that poor economic projections in Europe in the future will lead to strong opposition from EU member states that 
Turkey is admitted. Third, is that Turkey implements in full all reforms, which may lead it to qualify for membership, economic reforms lead to a boom in Turkey's economy and it becomes a regional power, with its neo-Ottoman tendencies, rejects the EU membership. The final scenario is the rejection of the European project from the Turkish society, arising from what it perceives as anti-Muslim discrimination and chooses to no longer pursue EU membership.

\section{Conclusion}

In conclusion, as things stand now, there is no indication that in this time scenario four could happen, it appeared that scenario four had already been passed when Turkey was turned down in 2004 that was when popular support for the membership dropped from within the Turkish society, but that has not made the Turks abandon the project. If any of the scenarios will come to play, it may likely be scenario one or three. Scenario four can only be possible if another attempt is made by Turkey and it receives a negative response from the EU, then it will be almost certain that the entire Turkish society will withdraw from the membership project. If after all the reforms and careful adoption of the European agenda since the 1920's, and after being turned down in 2005, almost ten years ago, and it is certain that much progress has been made in meeting the membership criteria by now, and for this, no reason will be sufficient for the EU to give for rejecting Turkey's membership from 2014-2015. There are no egalitarian societies in the world, and many have commended the Turks for such grand transformation of their entire society over the last several decades, just to belong to the European community. After all the Marxist philosophy was criticized as utopian in nature, for advocating a perfect society, and in the same vein, the EU criteria sometimes appear utopian to some countries and have remained a mirage for countries like Turkey, perhaps it was created for them. The EU stands a better chance of making changes inside Turkey if it is a member of the Union, and all outstanding issues, including that of Cyprus and the Kurds, could be resolved within the framework of the EU, but then it is highly unlikely for the Republic of Turkey to cooperate in resolving both the Kurdish issue and that of Cyprus once it becomes a member of the EU. However, the words of Stefan Fule clearly show the possibility of Turkey's membership despite the continued turbulence in the membership process and relations between Turkey and the EU. Despite the failure of the 2010 bid by Turkey over the Cyprus issue, the EU and Turkey again opened talks in 2016, but as reported, again relations between the EU and Turkey have turned sour after the crackdown by Turkey's Erdogan after the July 2016 coup in which hundreds of people were arrested in Turkey. The EU maintains that the arrests made were unconstitutional. Reuters (2016)

\section{References}

Dorothee Schimid, (2011) Turkey, The EU and the Middle East puzzle; Cooperation or mutual testing ahead, Atlantic Council.

European Union center (2008) North Carolina, EU Briefings, Turkeys Quest for EU Membership.

Gokhan Saz, (2012) The political implications of European integration of Turkey: political scenario's and major stumbling blocks, Vienna.

Ion Berindan, (2010) When Turkish Greatness meets EU values; How the perceptions influence Turkey-EU relationship, Romania.

Jens Alber, (2007) Where Turkey stands in Europe and why it should be admitted into the EU. Berlin.

Kemal Kirisci, (2003) The Kurdish Question and Turkish foreign policy.

Michael Aristidou, (2004) The real reason's why Turkey is not allowed in the EU.

Neil Nugent, (2005), Turkey's Membership Application for EU, Florida.

Open society foundation, (2009) Reflections of EU- Turkey relations in the Muslim world. Istanbul. 
Stefan Fule, (2012) Turkey and the EU: Common challenges, common future, European Commission.

Seyma Akyol, EU membership process of Turkey; the effects of human right violations and lack of democracy in Turkey's EU membership process.

Sule Toktas, Bulent Aras, (2009) The EU and minority rights in Turkey. Political science Quarterly, vol 124.

Tribune Media Services, (2005) Does Europe want Turkey?

Zalmay Khalilzad, Ion O. Lesser, Stephen Larrabee, (2000) The future of Turkish-Western relations; Towards a strategic plan, Santa Monica.

Ziya Onis, (2004) Turkey and the Middle East after September 11: The importance of the EU dimension, Istanbul.

$29^{\text {th }}$ meeting of the EU-Turkey Joint Consultative Committee, (2011) Joint declaration, Istanbul.

Factbox: (2016) Turkey's Collapsing www.reuters.com

\section{Copyrights}

Copyright for this article is retained by the author(s), with first publication rights granted to the journal.

This is an open-access article distributed under the terms and conditions of the Creative Commons Attribution license (http://creativecommons.org/licenses/by/4.0/). 